\title{
Utilization of $\alpha$-amylase (EC 3.2.1.1) resistant maize and pea (Pisum sativum) starch in the rat
}

\author{
BY R. M. FAULKS, SUSAN SOUTHON AND G. LIVESEY \\ Institute of Food Research, Norwich Laboratory, Colney Lane, Norwich NR4 7UA
}

(Received 3 March 1988 - Accepted 27 September 1988)

\begin{abstract}
1. The extent of utilization of $\alpha$-amylase $(E C 3 \cdot 2 \cdot 1 \cdot 1)$-resistant retrograded starches in vivo was assessed in male Wistar rats (about $100 \mathrm{~g}$ body-weight). All animals were given a fibre-free semi-synthetic basal diet (SS) containing sucrose as the only carbohydrate source, ad lib., for $13 \mathrm{~d}$. On day 14, after an overnight fast, rats were allocated to one of five dietary treatments (n 30):1, fibre-free basal SS diet; $2-5$, basal SS diet supplemented with $100 \mathrm{~g}$ sucrose, Solka floc (cellulose), resistant maize starch (RCS) or resistant pea (Pisum sativum) starch (RPS) $/ \mathrm{kg} \mathrm{diet.}$ Animals allocated to each dietary treatment were divided into three groups of ten rats which were given the appropriate diet for 8 or 9,17 or 18 and 29 or $30 \mathrm{~d}(8 / 9,17 / 18$ or $29 / 30 \mathrm{~d}$ groups respectively). Rats were fed on $12 \mathrm{~g} \mathrm{diet} / \mathrm{d}$ (treatment 1 ) or $13.2 \mathrm{~g} \mathrm{diet} / \mathrm{d}$ (treatments $2-5$ ) for the first $20 \mathrm{~d}$, and 14 or $15.4 \mathrm{~g} / \mathrm{d}$ respectively until the end of the experiment. Rats fed on the supplemented basal diets were thus given $10 \%$ more food to allow for the addition of the test carbohydrate. Faecal carbohydrate excretion was determined at intervals in the 17/18 $\mathrm{d}$ groups. At the end of each experimental period animals were killed after consuming their daily food ration and small intestinal length, weight of caecal and ileal contents and tissue, and $\mathrm{pH}$ of caecal contents measured. The amount of carbohydrate in the caecal and ileal contents from the $8 / 9$ and $17 / 18 \mathrm{~d}$ groups was determined.

2. Weights of ileal and caecal contents, caecal tissue and faecal output were significantly greater at all time points for rats fed on the resistant starches compared with those fed on basal and sucrose-supplemented diets. Values were higher for RPS-fed rats than for RCS-fed rats.

3. The quantity of carbohydrate recovered from ileal and caecal contents showed that both RCS and RPS were partially digested and absorbed as carbohydrate, but that RPS was digested to a lesser extent.

4. The concentration of carbohydrate decreased between the ileal and caecal sites when RPS and RCS were given but was essentially unchanged when cellulose was given. This is consistent with rapid fermentation of a fraction of these starches.

5. Faecal carbohydrate elimination in the $17 / 18 \mathrm{~d}$ groups fed on RCS and RPS declined with time, which suggested an adaptive response resulting in increased utilization of the starches. This adaptive response was slower in the RPS-fed rats than the RCS-fed rats.

6. The present study indicates that, in the rat, there are significant differences in the utilization of resistant starches from different sources.
\end{abstract}

The starch in cooked foods, e.g. bread, breakfast cereals and potato, is known to retrograde on storage. Retrogradation, the formation of crystallites (predominantly small aggregates of highly structured hydrogen-bonded amylose) (Collinson, 1968), results in a fraction of the starch becoming resistant to hydrolysis by $\alpha$-amylase $(E C 3.2 .1 .1)$ both in vitro (Kerr, 1950) and in vivo (Bjorck et al. 1986). Other starch complexes, e.g. starch-lipid, may also be present, but these have been shown to be susceptible to slow digestion by $\alpha$-amylase (Holm et al. 1983). Starch fractions resistant to $\alpha$-amylase are collectively called resistant starch (RS) (Englyst et al. 1982) and manipulation of variables during processing of highstarch foods may be used to alter the levels of RS occurring in the product (Berry, 1986).

In vitro studies suggest that the $\alpha$-amylase-resistant fraction of starches would be resistant to in vivo digestion and, therefore, unavailable as carbohydrate. However, it is known that the efficiency of in vivo digestion is generally greater than that found in vitro (Dreher et al. 1984) and it has been reported that RS from high-amylose maize is susceptible to hydrolysis by human gut microflora (Englyst \& Macfarlane, 1986). It might be expected therefore that at least some of the RS present in the diet would be digested in the small intestine and that the remainder would be largely utilized via hydrolysis and 
microbial fermentation in the large bowel. Findings relating to RS digestion and fermentation in vivo, however, are limited and there is no knowledge of the possible differences in the utilization of RS from different food sources.

In the present study the fate and effects of $\alpha$-amylase RS prepared from maize and pea (Pisum sativum) starches was investigated in the rat. The RS were incorporated into semisynthetic diets at $100 \mathrm{~g} / \mathrm{kg}$ and given to rats for between 8 and $30 \mathrm{~d}$. At the end of each experimental period $(8 / 9,17 / 18$ or $29 / 30 \mathrm{~d})$ small intestine length, weights of caecal and ileal contents and tissue, and caecal $\mathrm{pH}$ were recorded. The amount of carbohydrate in caecal and ileal contents was measured and faecal carbohydrate excretion determined. The possibility of an adaptational response to longer-term feeding of these starches was also investigated. For comparison, rats fed on a basal semi-synthetic diet and a basal diet supplemented with sucrose (totally available as carbohydrate) or cellulose (unavailable as carbohydrate and substantially resistant to fermentation) were included in the study.

\section{MATERIALS AND METHODS}

\section{Extraction of pea starch}

Peas (var. Scout; $1 \mathrm{~kg}$ ) were soaked for $1 \mathrm{~h}$ in running tap water, covered with water and left to soak overnight at $4^{\circ}$, washed thoroughly in tap-water and then homogenized (Ultraturrax, Janke \& Kunkle $\mathrm{GmbH}$ ) for 2-3 min in approximately 5 litres sodium chloride solution $(20 \mathrm{~g} / 1)$. The slurry was washed through a $1 \mathrm{~mm}$ sieve with enough water to generate approximately 10 litres filtrate, which was passed through a $125 \mu \mathrm{m}$ sieve and left to settle for $1 \mathrm{~h}$ at room temperature. The resulting supernatant fraction was poured off and the remaining material centrifuged at $2000 \mathrm{rev} . / \mathrm{min}$ for $10 \mathrm{~min}$ at $10^{\circ}$. The supernatant fraction was removed and the residue mixed with 1 litre distilled water and recentrifuged. This procedure was repeated twice more and the residue suspended in absolute alcohol before filtration (Whatman filter paper no. 541) under vacuum. The residue was spread thinly on trays and left in a fume cupboard overnight to allow the solvent to evaporate. The dry residue was stored in air-tight containers. Samples of the material were subjected to acid hydrolysis using a modification of the method of Saeman et al. (1954) (12 M-sulphuric acid at $1^{\circ}$ for $18 \mathrm{~h}$ followed by dilution to $1 \mathrm{M}-\mathrm{H}_{2} \mathrm{SO}_{4}$ and heating to $100^{\circ}$ for $2 \mathrm{~h}$ in a boiling water-bath). Glucose, determined by a glucose oxidase ( $E C$ 1.1.3.4)-peroxidase ( $E C$ 1.11.1.7) method (Boehringer, cat. no. 124036), showed that the residue contained approximately $970 \mathrm{~g}$ glucan $/ \mathrm{kg}$ on a dry weight basis. Scanning electron microscopy showed that the material was mainly composed of starch granules with only minute traces of cell wall material.

\section{Preparation of $R S$}

Starch (Snowflake maize starch; Corn Products Co. (UK) Ltd, Manchester) or pea starch $(400 \mathrm{~g})$ was suspended in 4 litres calcium chloride solution $(4 \mathrm{~g} / \mathrm{l})$ and heated at $80-90^{\circ}$ until the viscosity increased to the point where the starch would not settle out. Gelation of the starch was completed by autoclaving at $121^{\circ}$ for 20 min after which the gel was left at $1^{\circ}$ for $48 \mathrm{~h}$ to retrograde. The retrograded gels were warmed to room temperature. To this was added $375 \mathrm{ml}$ sodium chloride solution $(10 \mathrm{~g} / \mathrm{l})$ containing $40 \mathrm{~g}$ crude porcine $\alpha$-amylase (Sigma Chemical Co., Poole, Dorset) which had been centrifuged to remove suspended solids. The mixture was homogenized, left to stand for $10 \mathrm{~min}$, remixed, poured into 10-litre Duran glass bottles with loose-fitting tops and incubated at $37^{\circ}$ overnight. After mixing, the material was centrifuged at $2000 \mathrm{rev} . / \mathrm{min}$ for $10 \mathrm{~min}$ at $10^{\circ}$, the supernatant fraction discarded, and the residue thoroughly washed with distilled water and recentrifuged five times before freeze drying and weighing. Approximately $40 \%$ of the pea starch and $20 \%$ 
Table 1. Composition of diets $(\mathrm{g} / \mathrm{kg})$

$\begin{array}{lr}\text { Basal diet } \ddagger & \\ \text { Casein } & 168 \\ \text { Sucrose } & 692 \\ \text { Maize oil } & 80 \\ \text { Minerals } & 40 \\ \text { Vitamin mix } \uparrow & 20 \\ \text { Methionine } & 2\end{array}$

Test diets $\ddagger$ (basal diet with the addition $(100 \mathrm{~g} / \mathrm{kg}$ diet) of one of the following) Sucrose

Cellulose§

Resistant maize starch $\|$

Resistant pea (Pisum sativum) starch\|

* Provided (g/kg diet): $\mathrm{CaHPO}_{4} 13 \cdot 00, \mathrm{CaCO}_{3} 8 \cdot 2, \mathrm{KCl} 7 \cdot 03, \mathrm{Na}_{2} \mathrm{HPO}_{4} 7 \cdot 4, \mathrm{MgSO}_{4}, \mathrm{H}_{2} \mathrm{O} 4 \cdot 00, \mathrm{MnSO}_{4} \cdot \mathrm{H}_{2} \mathrm{O}$ $0.18, \mathrm{ZnCO}_{3} 0 \cdot 01, \mathrm{FeSO}_{4} \cdot \mathrm{H}_{2} \mathrm{O} 0 \cdot 144, \mathrm{CuSO}_{4} 0.015 \mathrm{KIO}_{3} 0.001$.

$\dagger$ Provided (mg/kg diet): nicotinic acid 60, cyanocobalamin in mannitol (Glaxo) 50, calcium D-pantothenate 40 , thiamin hydrochloride 10 , riboflavin 10 , pteroylmonoglutamic acid 5, D-biotin 1, menadione 1, Rovimix E-25 (Roche) 300, Rovimix A-500 (Roche) 25, Rovimix $\mathrm{D}_{3}-500$ (Roche) 15, choline bitartrate 1800 .

$\ddagger$ For feeding regimen see below.

$\S$ Solka floc (Johnsen, Jurgensen and Wettre Ltd, Wokingham, Berks).

\| For details of preparation of resistant starches, see p. 292.

of the maize starch remained after this procedure and this material was designated as the RS fraction. Scanning electron microscopy showed that it was an amorphous material and no intact starch granules were observed.

\section{Animals and diets}

Male Wistar rats (n 150), weighing approximately $100 \mathrm{~g}$, were randomly allocated to one of five dietary treatments, each consisting of three groups of ten animals. Rats were caged singly in polypropylene cages with wire-mesh bottoms and tops in a room at $21^{\circ}$, having a $12 \mathrm{~h}$ light $-12 \mathrm{~h}$ dark cycle. Water was available at all times. All animals were given a fibrefree basal semi-synthetic diet, with sucrose as the only source of carbohydrate, ad lib. for $13 \mathrm{~d}$. On day 14, after an overnight fast, rats were given the following diets (Table 1): treatment 1 , fibre-free basal semi-synthetic diet; treatments $2-5$, basal diet supplemented by the addition of $100 \mathrm{~g}$ sucrose, Solka floc (cellulose), resistant maize starch (RCS) or resistant pea starch (RPS) $/ \mathrm{kg}$ diet. Rats in each dietary treatment were fed on the diet for 8 or 9,17 or 18 and 29 or $30 \mathrm{~d}(8 / 9,17 / 18$ or $29 / 30 \mathrm{~d}$ groups respectively). Five rats from each dietary treatment were killed in random order on each of the specified days. It was necessary to kill the rats in each of these groups over a $2 \mathrm{~d}$ period so that all the animals were examined between 2 and $4 \mathrm{~h}$ after consuming their daily portion of food, during which time the animals would be in a steady state with regard to stomach emptying and digestion (G. Livesey, unpublished results). Throughout the study food intake was limited to an amount that the rats would consume in $1 \mathrm{~h}$, between 9.30 and 10.30 hours. This feeding regimen was adopted so that all the animals had a similar feeding pattern throughout the study and hence would be strictly comparable. Animals in the $8 / 9$ and $17 / 18 \mathrm{~d}$ groups of treatment 1 (basal diet only) received $12 \mathrm{~g} / \mathrm{d}$, whilst those in the $29 / 30 \mathrm{~d}$ group received $12 \mathrm{~g} / \mathrm{d}$ for the first $20 \mathrm{~d}$ and $14 \mathrm{~g} / \mathrm{d}$ thereafter. Rats in treatments $2-5$ (supplemented basal diet) were given $10 \%$ more food each day to allow for the addition of the test material. Rats in all treatments therefore received the same amount of basal diet throughout the study. Body-weights of every animal were recorded at intervals during the study and immediately after killing. 


\section{Faecal collections}

Faeces from each of the five dietary treatments in the $8 / 9$ and $17 / 18 \mathrm{~d}$ groups were collected and pooled daily by group and dietary treatment for subsequent dry-weight measurements. In addition faeces from the $17 / 18 \mathrm{~d}$ groups were analysed as intervals for carbohydrate content. Faeces from the rats in the $29 / 30$ d groups were collected from individual animals and pooled for each animal for $7-\mathrm{d}$ periods for dry weight measurements and future determination of energy balance. All faeces were kept at $-20^{\circ}$ between collections and before analysis.

\section{Sampling of tissues and digesta}

Rats were deeply anaesthetized by intraperitoneal injection of sodium pentabarbital $(160 \mathrm{mg} / \mathrm{ml} ; 2 \mathrm{ml} / \mathrm{kg}$ body-weight) and killed by cervical dislocation. The abdomen was opened, the caecum isolated by ligaturing to prevent leakage of the contents, the small intestine removed and the total length of small intestine measured with minimal stretching. The contents of the ileum (distal $50 \%$ of small intestine) were collected for the determination of dry matter by gently squeezing out with forceps into a plastic vial. Total caecal weight was then recorded and the $\mathrm{pH}$ of the contents measured with a microelectrode. Caecal contents were retained for wet-dry weight and carbohydrate analysis, and caecal tissue was taken for wet-dry weight determination. Caecal and ileal tissues and contents were freeze-dried for dry matter determinations. After drying, the digesta were ground to a uniform powder by vigorously shaking the vial after the addition of two, $12 \mathrm{~mm}$, PTFEcoated magnetic stirrer bars. Freeze-dried faeces were ground in a small coffee mill. All dried ground samples and tissues were stored at room temperature in air-tight plastic vials.

\section{Carbohydrate determination}

Dry digesta $(50 \mathrm{mg})$ were weighed into $50-\mathrm{ml}$ screw-top glass centrifuge tubes containing a $12 \mathrm{~mm}$ PTFE-coated stirrer bar, and $2 \mathrm{ml}$ cold $\left(4^{\circ}\right) 12 \mathrm{M}-\mathrm{H}_{2} \mathrm{SO}_{4}$ added. The carbohydrate was dispersed by stirring for $18 \mathrm{~h}$ at $1^{\circ}$ and hydrolysed for $2 \mathrm{~h}$ at $100^{\circ}$ in a boiling waterbath with continuous stirring after dilution to $1 \mathrm{M}-\mathrm{H}_{2} \mathrm{SO}_{4}$. Glucose was measured using a glucose oxidase-peroxidase method. Ileal contents were checked for sucrose using highperformance liquid chromatography. Free sugars, extracted from $50 \mathrm{mg}$ dry ileal contents using $3 \times 10 \mathrm{ml}$ boiling ethanol $(800 \mathrm{ml} / \mathrm{l})$ were reduced to dryness under vacuum at $50^{\circ}$, made up in acetonitrile-water $(70: 30, \mathrm{v} / \mathrm{v})$ and separated on a Waters carbohydrate column (Millipore-Waters). The mobile phase, acetonitrile-water $(70: 30, \mathrm{v} / \mathrm{v})$, was pumped at $2.5 \mathrm{ml} / \mathrm{min}$ and eluted components detected by refractive index.

\section{Statistics}

The GENSTAT package was used for all statistical analysis. Means for body-weight gain and faecal dry matter output for the five diets were compared by one-way analysis of variance (Table 2). Means for small intestinal length, dry weights of ileum and ileal contents, dry weights of caecum and caecal contents, and caecal $\mathrm{pH}$ for rats fed on the five diets over the three experimental periods were compared by a two-way analysis of variance (Table 3 ). Since there was no significant interactive (time $\times$ diet) effect, means for each experimental time period were averaged over diets and means for each diet were averaged over time. The carbohydrate contents of the dry ileal and caecal contents for four of the diets were compared by two-way analysis of variance at each of two experimental time periods $(8 / 9$ and $17 / 18 \mathrm{~d}$ ) after $\log _{10}$ transformation of the values to equalize variances (Table 4 ). Geometric means are also tabulated in Table 4 to assist interpretation of the results. 
Table 2. Food intake, body-weight gain and faecal dry matter output of rats fed on a basal semi-synthetic diet (SS) or SS diet with added $(100 \mathrm{~g} / \mathrm{kg})$ sucrose, cellulose, resistant maize starch (RCS) or resistant pea (Pisum sativum) starch (RPS) for 29-30 d*

(Values are means for ten rats)

\begin{tabular}{|c|c|c|c|c|c|c|c|}
\hline Dietary treatment ${ }^{*}$. & Basal & Sucrose & Cellulose & RCS & RPS & $\begin{array}{c}\text { SED } \\
(45 \mathrm{df})\end{array}$ & LSD \\
\hline Food intake $(\mathrm{g})$ & $345 \cdot 0$ & 379.5 & $379 \cdot 5$ & 379.5 & $379 \cdot 5$ & - & - \\
\hline Body-wt gain (g) & 88.0 & 105.0 & 97.0 & $120 \cdot 0$ & $112 \cdot 0$ & $4 \cdot 30$ & $8 \cdot 66$ \\
\hline Faecal output (g) & $10 \cdot 7$ & $10 \cdot 7$ & $42: 3$ & $14 \cdot 1$ & $20 \cdot 1$ & 0.84 & 1.69 \\
\hline
\end{tabular}

SED, standard error of difference between any two means (for statistical treatment, see p. 294); LSD, least significant difference $(P<0.05)$.

* For details of dietary treatments, see p. 293.

Standard error of differences (SED) of means and the residual degrees of freedom are given in each table to allow the significance of any differences in comparable values to be found by reference to statistical tables: $\left(\operatorname{mean}_{1}-\operatorname{mean}_{2}\right) / \mathrm{SED}=t$ with tabulated residual degrees of freedom.

\section{RESUL'TS}

Rats fed on the unsupplemented basal diet had a lower body-weight gain over the 29/ $30 \mathrm{~d}$ experimental period than all other groups $(P<0.05)$, and those rats fed on the RCSsupplemented diet had the highest mean value for body-weight gain (Table 2).

There were marked and consistent differences in faecal output between the five dietary treatments. Rats fed on the basal and sucrose-supplemented diets produced similar amounts of faeces, expressed as a mean dry weight ( $\mathrm{g} / \mathrm{rat}$ ), over the $29 / 30 \mathrm{~d}$ experimental period with values for the RCS, RPS and cellulose treatments being 32, 88 and $295 \%$ greater $(P<0.001)$ than the basal and sucrose-supplemented treatments respectively (Table 2).

The effect of cellulose and the RS on small intestinal growth appeared to be minimal, but both the RCS- and RPS-fed rats had significantly increased $(P<0.001)$ dry weight of caecal tissue compared with rats fed on the other three diets, rats given the RPS having the highest mean value (Table 3). Mean dry weight of caecal contents was also significantly higher $(P<0.05-P<0.01)$ in the RPS-fed rats compared with all other groups and this was accompanied by a significant increase $(P<0.001)$ in dry weight of ileal contents, and a reduction $(P<0.001)$ in the $\mathrm{pH}$ of caecal contents, compared with the basal and sucrosesupplemented animals. Similar but generally less marked differences were seen in the rats given RCS (Table 3). The caecal tissue weight of the rats fed on cellulose was not significantly increased compared with rats given the basal or sucrose-supplemented diets, although the dry weights of ileal and caecal contents recovered from these animals were significantly higher $(P<0.001)$ than those for the basal and sucrose-supplemented groups. Although it is known that sucrose is rapidly hydrolysed and absorbed in the proximal intestine, it was considered possible that the complex carbohydrate added to the semisynthetic diet may have influenced the site of sucrose absorption thus resulting in the presence of sucrose in the ileum at the time of death. This would have affected the subsequent carbohydrate analysis of the ileal contents. However, no sucrose was detected in the ileal contents of any of the animals. At the end of both the 8/9 and 17/18 $\mathrm{d}$ feeding 
Table 3. Small intestinal (SI) length, dry weight of ileum and ileal contents, dry weight of caecum and caecal contents and caecal pH of rats fed on a basal semi-synthetic diet (SS) or $S S$ diet with added $(100 \mathrm{~g} / \mathrm{kg})$ sucrose, cellulose, resistant maize starch (RCS) or resistant pea (Pisum sativum) starch (RPS)*

(Values are means for each experimental time period (days) averaged over diets, and means for each diet averaged over experimental time periods)

\begin{tabular}{|c|c|c|c|c|c|c|}
\hline & \multirow{2}{*}{\multicolumn{3}{|c|}{ Ileum }} & \multicolumn{3}{|c|}{ Caecum } \\
\hline & & & & \multirow[b]{2}{*}{$\begin{array}{c}\text { Tissue } \\
\text { dry wt } \\
\text { (mg) }\end{array}$} & \multicolumn{2}{|c|}{ Contents } \\
\hline & $\begin{array}{c}\text { SI } \\
\text { length } \\
(\mathrm{mm})\end{array}$ & $\begin{array}{c}\text { Tissue } \\
\text { dry wt } \\
\text { (mg) }\end{array}$ & $\begin{array}{l}\text { Contents } \\
\text { dry wt } \\
\text { (mg) }\end{array}$ & & $\begin{array}{c}\text { dry wt } \\
\text { (mg) }\end{array}$ & $\mathrm{pH}$ \\
\hline \multicolumn{7}{|l|}{ Time period (d) } \\
\hline $8-9$ & 1130 & 163 & 184 & 178 & 270 & 6.97 \\
\hline $17-18$ & 1130 & 161 & 208 & 170 & 320 & $7 \cdot 20$ \\
\hline $29-30$ & 1140 & 172 & 316 & 215 & 399 & $7 \cdot 14$ \\
\hline SED (135 df $)$ & 11 & 3.0 & $14 \cdot 3$ & 7.0 & 16.9 & 0.04 \\
\hline \multicolumn{7}{|l|}{ Diet $^{*}$} \\
\hline Basal (SS) & 1130 & 164 & 183 & 164 & 221 & $7 \cdot 33$ \\
\hline Sucrose & 1140 & 175 & 175 & 165 & 245 & $7 \cdot 26$ \\
\hline Cellulose & 1130 & 159 & 350 & 166 & 401 & 7.05 \\
\hline $\mathrm{RCS}$ & 1140 & 158 & 218 & 205 & 325 & 6.92 \\
\hline RPS & 1130 & 171 & 256 & 238 & 457 & $6 \cdot 95$ \\
\hline SED (135 df $)$ & 14 & $3 \cdot 9$ & $18 \cdot 5$ & $9 \cdot 0$ & $21 \cdot 8$ & 0.06 \\
\hline
\end{tabular}

SED, standard error of difference between any two means (for statistical treatment, see p. 294).

* For details of dietary treatments, see p. 293 and Table 1.

Table 4. Carbohydrate (as glucose) expressed as a percentage of dry weight of ileal and caecal contents from rats fed on a basal semi-synthetic diet (SS) or SS diet with added $(100 \mathrm{~g} / \mathrm{kg})$ cellulose, resistant maize starch (RCS) or resistant pea (Pisum sativum) starch (RPS) for both $8 / 9$ and $17 / 18$ d experimental periods*

(Values are $\log _{10}$ means with geometric means for ten rats)

\begin{tabular}{|c|c|c|c|c|c|}
\hline Dietary treatment* & Basal & Cellulose & RSC & RPS & $\begin{array}{c}\text { SED } \\
(72 \mathrm{df})\end{array}$ \\
\hline \multicolumn{6}{|l|}{$8 / 9 \mathrm{~d}$} \\
\hline \multicolumn{6}{|l|}{ Ileal contents } \\
\hline $\log _{10}$ & -0.426 & 1.684 & $1 \cdot 383$ & 1.646 & 0.0545 \\
\hline Geometric mean $(\%)$ & 0.4 & $48 \cdot 3$ & $24 \cdot 2$ & $44 \cdot 3$ & - \\
\hline \multicolumn{6}{|l|}{ Caecal contents } \\
\hline $\log _{10}$ & -0.598 & $1 \cdot 764$ & 0.839 & 1.011 & - \\
\hline Geometric mean $(\%)$ & $0 \cdot 3$ & $58 \cdot 1$ & 6.9 & $10 \cdot 3$ & - \\
\hline \multicolumn{6}{|l|}{$17 / 18 \mathrm{~d}$} \\
\hline \multicolumn{6}{|l|}{ Ileal contents } \\
\hline $\log _{10}$ & -2.000 & 1.697 & 1.437 & 1.697 & 0.0436 \\
\hline Geometric mean $(\%)$ & 0.01 & $49 \cdot 8$ & $27 \cdot 4$ & $49 \cdot 8$ & - \\
\hline \multicolumn{6}{|l|}{ Caecal contents } \\
\hline $\log _{10}$ & -0.901 & 1.745 & $-0 \cdot 229$ & $1 \cdot 217$ & \\
\hline Geometric mean $(\%)$ & 0.1 & $55 \cdot 6$ & 0.6 & $16-5$ & - \\
\hline
\end{tabular}

SED, standard error of difference between any two means (for statistical treatment, see p. 294).

* For dietary treatment, see p. 293. 


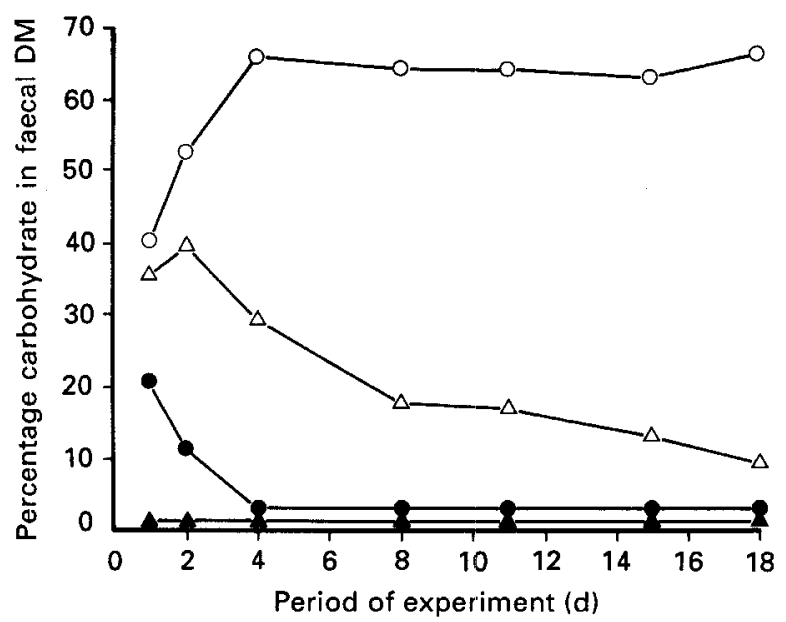

Fig. 1. Changes in faecal carbohydrate (as glucose) excretion expressed as a percentage of faecal dry matter (DM) for rats fed on $12 \mathrm{~g}$ basal semi-synthetic (SS) diet/d with sucrose as the only carbohydrate source $(\mathbf{A}-\mathbf{A})$, or $12 \mathrm{~g}$ SS diet plus $1.2 \mathrm{~g}$ resistant maize starch (-O), resistant pea (Pisum sativum) starch $\left(\triangle^{-} \triangle\right)$ or cellulose $\left(\mathrm{O}^{-} \mathrm{O}\right)$, for $17 / 18 \mathrm{~d}$. Analyses were performed on faeces collected and pooled daily for ten rats per group.

periods, the caecal contents from the cellulose-fed animals contained the highest $(P<0.001)$ proportion of glucan (measured as glucose), values being approximately $57 \%$ dry matter, whereas the values for rats fed on the basal diet were $<1 \%$ (Table 4). Rats on the RPS treatment had the second highest values. The concentrations of glucan in the ileal and caecal contents from the RPS-fed rats were significantly greater $(P<0.01)$ than those for the RCS treatment at both $8 / 9$ and $17 / 18 \mathrm{~d}$. Differences in total glucan (the product of weight of dry contents and glucan content of dry matter) in the ileum and caecum followed exactly the same trends as those observed for glucan concentration. The glucan content of the dry faeces from the groups maintained on the experimental diets for $17 / 18 \mathrm{~d}$ is shown in Fig. 1. After an initial adjustment period the glucan concentration in faeces from rats in the cellulose treatment stabilized at approximately $65 \%$ of the dry matter. The amount of glucan, as a percentage of dry matter, in faeces from the RCS- and RPS-fed rats was initially 20 and $40 \%$ respectively and values for both treatments declined with time. By day 18 the glucan values were 2.5 and $10 \%$ for RCS and RPS treatments respectively, the RCSfed rats having reached a minimum value by day 5 whereas the values for the RPS-fed rats continued to fall throughout the $18 \mathrm{~d}$ period. Only traces of glucan were found in the faeces from rats fed on the sucrose-supplemented diet (Fig. 1). Faecal carbohydrate excretion followed a similar pattern throughout the $18 \mathrm{~d}$ feeding period whether glucan was expressed as a percentage of dry weight or as a percentage of the carbohydrate intake, i.e. apparent digestibility (Figs 1 and 2).

\section{DISCUSSION}

It is generally assumed that the cooking of foods before eating makes the starch more available for digestion and absorption. This may occur when the food is eaten shortly after cooking, before significant retrogradation takes place or when the extent or rate of retrogradation is limited by other food components (Foster, 1965). There are, however, many commonly used cooked starchy foods which are often kept for at least a few days, 


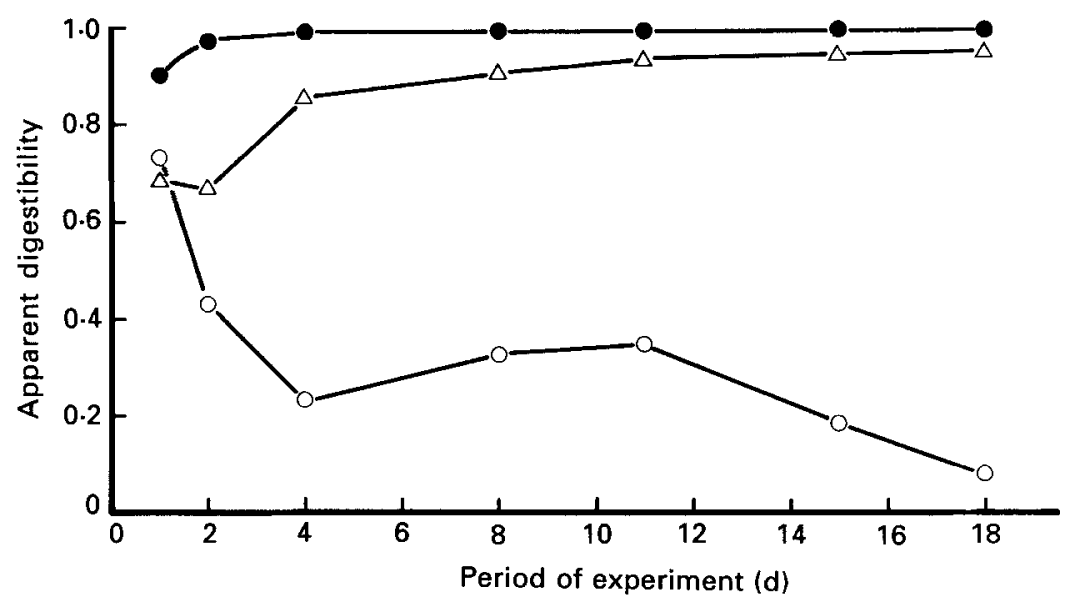

Fig. 2. Apparent digestibility (intake-excreted)/intake) of carbohydrate sources in rats fed on $12 \mathrm{~g}$ basal semi-synthetic diet (SS)/d with sucrose as the only source of carbohydrate plus $1-2 \mathrm{~g}$ resistant maize starch (O-O), resistant pea (Pisum sativum) starch $(\triangle-\triangle)$ or cellulose $\left(O^{-} O\right) / \mathrm{d}$ for the $17 / 18 \mathrm{~d}$ groups. Analyses were performed on faeces collected and pooled daily for ten rats per group.

and sometimes much longer before being eaten (for example, baked foods such as bread, and canned, frozen and cook-chilled foods) giving sufficient time for retrogradation of starch to occur (Swinkels, 1985). The starch in such foods may behave in a manner similar to the starch gels presently investigated; that is, a variable amount may become resistant to exhaustive $\alpha$-amylase-catalysed hydrolysis in vitro and to mammalian enzymes in vivo.

Feeding studies have already been conducted using whole foods (Englyst \& Cummings, 1985) or starches (Berry, 1986) still containing a large proportion of carbohydrate susceptible to $\alpha$-amylase. These studies have not discriminated between available starch, starch-resisting mammalian digestive enzymes and starch which escapes digestion for other reasons such as hindrance by the food matrix. In the present study the isolated RS fractions were the only source of starch present in the diets fed to rats.

The increase in dry weight of digesta from the ileum, caecum and that eliminated in the faeces gave the first indication that a proportion of both the RS escaped digestion and fermentation (Tables 2 and 3).

The occurrence of carbohydrate in the faeces of rats fed on cellulose, RPS and RCS (Fig. 1) also illustrated the extent to which these complex carbohydrates escaped digestion and fermentation in vivo. Throughout the whole feeding period RCS was more extensively utilized than RPS, which in turn was utilized more than cellulose. The apparent digestibility of these complex carbohydrates (Fig. 2) during the first few days of the feeding study is consistent with the accumulation of these carbohydrates in the alimentary tract, rather than the rapid elimination in the faeces, together with some adaptation towards increased utilization of the RS. The adaptation appeared to continue slowly for some time with RPS, though was apparently completed by day 5 when RCS was given. Adaptation to the utilization of the RS may, in part, result from recolonization of the large bowel with microorganisms following the 2-week period when no complex carbohydrates were given.

It has been shown that the two RS used in the present experiment are susceptible to fermentation by rat faecal microflora in vitro (Wyatt \& Horn, 1988). Significant decreases $(P<0.001)$ in the $\mathrm{pH}$ of caecal digesta occurred in RCS- and RPS-fed rats by comparison 
with sucrose-fed animals, which also indicates that these starches undergo some fermentation in vivo. The glucan contents of the dry digesta from the ileum and caecum were similar at $8 / 9$ and $17 / 18 \mathrm{~d}$ in those rats fed on the cellulose supplement. In contrast, the glucan content of the dry caecal digesta was 29 and $23 \%$ of the dry ileal contents value at $8 / 9 \mathrm{~d}$, and 2 and $33 \%$ at $17 / 18 \mathrm{~d}$ for RCS and RPS respectively. Thus the RS appear to be much more rapidly fermented than cellulose, with the RCS being more susceptible to fermentation than RPS. Since only traces of carbohydrate were found in the ileal and caecal digesta from the rats given basal or sucrose-supplemented diets, the larger amounts found at these sites in rats given cellulose or RS supplements must have been unabsorbed carbohydrate of dietary origin (Table 4).

At the ileal site, the quantity of carbohydrate recovered from animals fed on the RCS and RPS was approximately 50 and $96 \%$ respectively of that from the cellulose-fed rats at both $8 / 9 \mathrm{~d}$ and $17 / 18 \mathrm{~d}$. A possible explanation for this is that the RCS was to some extent digested and absorbed in the small intestine, the RPS having a similar resistance to digestion as cellulose. The reasons for this are unknown, but may be a result of exposure of the RS to the low $\mathrm{pH}$ conditions present in the rat stomach or by removal, in vivo, of factors that confer resistance in RCS to $\alpha$-amylase hydrolysis in vitro. Alternatively, there may be differences in the rate of transit of the RS along and out of the small intestine. However, the latter suggestion seems unlikely. Since the glucan concentrations of the dry ileal contents were similar in the $8 / 9 \mathrm{~d}$ and $17 / 18 \mathrm{~d}$ groups, there was no evidence of an adaptive increase in the capacity of the small intestine to digest, and thereby salvage carbohydrate, nor was there any increase in small intestinal length in rats fed on the complex carbohydrates such as occur in animals fed on viscous polysaccharides (Johnson et al. 1984; Johnson \& Gee, 1986).

The apparent digestibility of the RS in the present study (Fig. 2) was generally greater than occurs with most non-starch polysaccharides from whole foods, e.g. carrots (Nyman et al. 1986), but similar to some soluble non-starch polysaccharides, e.g. guar gum, gum arabic (Nyman \& Asp, 1982; McLean et al. 1983). As with non-starch polysaccharides in whole foods and as isolates, the RS increased faecal dry matter. To this extent RS and nonstarch polysaccharides are similar. An important difference appears to be the extent to which they are available as carbohydrate.

In summary, in the rat, RCS appears to be partially digested and available as carbohydrate, the remainder being almost totally fermented after an initial adaptive period. In contrast RPS appears both less available and more resistant to fermentation. The present study indicates that substantial differences in utilization in vivo may exist between RS from various foods.

The authors gratefully acknowledge the financial support of the Ministry of Agriculture, Fisheries and Food, Mrs J. Cooke for her skilled animal care, Mrs Z. Piper for her excellent technical assistance and $\mathrm{Mr}$ A. J. A. Wright for statistical advice.

\section{REFERENCES}

Berry, C. S. (1986). Resistant starch : formation and measurement of starch that survives exhaustive digestion with amylolytic enzymes during the determination of dietary fibre. Journal of Cereal Science 4, 301-314.

Bjorck, I., Nyman, M., Pedersen, B., Siljestrom, M., Asp. N-G. \& Eggum, B. O. (1986). On the digestibility of starch in wheat bread - studies in vitro and in vivo. Journal of Cereal Science 4, 1-11.

Collinson, R. (1968). In Starch and its Derivatives, pp. 194-201 [J. A. Radley, editor]. London: Chapman \& Hall.

Dreher, M. L., Dreher, C. J. \& Berry, J. W. (1984). Starch digestibility of foods: a nutritional perspective. CRC Critical Reviews in Food Science and Nutrition 20, 47-71. 
Englyst, H. N. \& Cummings, J. H. (1985). Digestion of the polysaccharides of some cereal foods in the human small intestine. American Journal of Clinical Nutrition 42, 778-787.

Englyst, H. N. \& Macfarlane, G. T. (1986). Breakdown of resistant and readily digestible starch by human gut bacteria. Journal of the Science of Food and Agriculture 37, 699--706.

Englyst, H. N., Wiggins, H. S. \& Cummings, J. H. (1982). Determination of the non-starch polysaccharides in plant foods by gas-liquid chromatography of the constituent sugars as alditol acetates. Analyst 107, 307-318.

Foster, J. F. (1965). In Starch Chemistry and Technology, vol. 1, pp. 350-353. [R. L. Whistler and E. F. Paschall, editors]. London Academic Press.

Holm, J., Bjorck, I., Ostrowska, S., Eliasson, A.-C., Asp, N.-G., Larsson, K. \& Lundquist, I. (1983). Digestibility of amylose-lipid complexes in vitro and in vivo. Starch/Starke 35, 294-297.

Johnson, I. T. \& Gee, J. M. (1986). Gastrointestinal adaptation in response to soluble non-availabile polysaccharides in the rat. British Journal of Nutrition 55, 497-505.

Johnson, I. T., Gee, J. M. \& Mahoney, R. R. (1984). Effects of dietary supplements of guar gum and cellulose on intestinal cell proliferation, enzyme levels and sugar transport in the rat. British Journal of Nutrition $\mathbf{5 2}$, $477-487$.

Kerr, R. W. (1950). Chemistry and Industry of Starch, pp. 166-167. New York: Academic Press.

McLean, R. A. H., Eastwood, M. A., Brydon, W. G., Anderson, J. R. \& Anderson, D. M. W. (1983). A study of the effects of dietary gum arabic in humans. American Journal of Clinical Nutrition 37, 368-375.

Nyman, M. \& Asp, N.-G. (1982). Fermentation of dietary fibre components in the rat intestinal tract. British Journal of Nutrition 47, 357-366.

Nyman, M., Asp, N.-G., Cummings, J. H. \& Wiggins, H. (1986). Fermentation of dietary fibre in the intestinal tract: comparison between man and rat. British Journal of Nutrition 55, 487-496.

Saeman, J. F., Moore, W. E., Mitchell, R. L. \& Millet, M. A. (1954). Techniques for the determination of pulp constituents by quantitative paper chromatography. TAPPI 37, 336-343.

Swinkels, J. J. M. (1985). Composition and properties of commercial native starches. Starch/Starke $37,1-5$.

Wyatt, G. \& Horn, N. (1988). Fermentation of resistant food starches by human and rat intestinal bacteria. Journal of the Science of Food and Agriculture 44, 281-288. 